\title{
Note
}

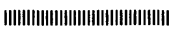

\section{Rapid Decrease in DNA Content Induced by Gamma Irradiation in Cultured Cells of Tobacco ${ }^{\dagger}$}

\author{
Akira Kanazawa ${ }^{\dagger}$, Mitsuhiro Hatanaka, Nobuhiro Tsutsumi, Hoshio Eguchi \\ and Atsushi HIRAI \\ Laboratory of Radiation Genetics, Graduate School of Agricultural Life Science, \\ The University of Tokyo \\ 1-1-1, Yayoi, Bunkyo-ku, Tokyo 113-8657, Japan \\ ${ }^{*}$ Research Center for Nuclear Science and Technology, The University of Tokyo \\ 2-11-16, Yayoi, Bunkyo-ku, Tokyo 113-0032, Japan
}

Received November 19, 1997

\begin{abstract}
The effect of gamma irradiation on the growth rate, on the amount of soluble protein and on the amount of DNA in tobacco calli was analyzed. A significant decrease in the amount of DNA was detected in the calli of every growth stage after incubation for $24 \mathrm{~h}$ following irradiation at a dose that severely affected the growth of calli, although only a slight change was detected in the amount of soluble protein. No difference in the effect of irradiation on protein and DNA contents was detected among calli of different growth stages, although the amounts of protein and DNA in calli in each growth stage were different. The extent of the decrease in the amount of DNA of calli depended on both the dose which ranged from 0-300 Gy and the time of incubation after irradiation. These results suggest that the rapid decrease in the DNA content of calli after irradiation is due to cellular systems that are induced by irradiation and that result in enzymatic degradation of DNA.
\end{abstract}

Key Words: gamma irradiation, callus culture, tobacco, DNA degradation

\section{Introduction}

Cultured cells are considered to be suitable materials for analyzing the effect of ionizing radiation on eukaryotic systems, since they continue

\footnotetext{
†タバコカルスにおける $\gamma$ 線照射によって誘導さ れる急速な DNA 量の減少。金澤 章"t, 畠中光 宏, 堤 伸浩, 江口星雄 ${ }^{*}$, 平井篤志: 東京大学 大学院農学生命科学研究科放射線遗伝学研究室, 113-8657 東京都文京区弥生 1-1-1, * 東京大学 原子力研究総合センター, 113-0032 東京都文 京区弥生 2-11-16。”現在 北海道大学農学部植 物遺伝資源学講座，060-8589 札幌市北区北 9 条西 9 丁目。(Present address : Laboratory of Plant Genetics and Evolution, Faculty of Agriculture, Hokkaido University, Sapporo 060-8589, Japan.)
}

to proliferate at a fixed speed and are relatively homogeneous compared with the different cell types of highly organized tissues. Although cultured cells are routinely used for radiation studies of animal tissues, almost all the studies on the effects of ionizing radiation in plants have been done using highly organized tissues (for a review, see Ref. 1). Few such studies have been done on cultured cells of higher plants, especially in regard to the effect of ionizing radiation on the level of nucleic acids. Bajaj ${ }^{2)}$ found that gamma irradiation of Phaseolus vulgaris inhibited tissue culture growth and RNA synthesis, which subsequently inhibited protein synthesis. To our knowledge, however, there have been no detailed reports for 
changes in DNA content of cultured cells of higher plants by ionizing radiation, except for those of protoplast cultures in which elimination of DNA by irradiation was indirectly assayed by quantifying the amount of DNA remained in asymmetric hybrid cells (see, for example, Refs. $3-6)$.

In this study, we examined the effect of gamma irradiation on the growth of calli, and the levels of soluble protein and DNA of various growth phases of tobacco calli. The results indicate that DNA degradation occurred in a time-dependent manner following irradiation as was observed in animal cells ${ }^{7)}$ and suggested an involvement of enzymatic reactions in the degradation of DNA.

\section{Materials and Methods}

\subsection{Callus culture}

Calli of Nicotiana tabacum L. var. Burley 21 were induced from stem tissue of the plant. Segments of 2-week-old stem tissue were cultured on LS medium ${ }^{8)}$ that contained (per liter) $3 \mathrm{mg}$ indoleacetic acid (IAA), $3 \mathrm{mg}$ 1-naphthaleneacetic acid (NAA), $0.1 \mathrm{mg}$ kinetin and $3 \%(w / v)$ sucrose. The calli were maintained in the dark at 25 ${ }^{\circ} \mathrm{C}$ and were subcultured at 3-week intervals. Medium was adjusted to $\mathrm{pH} 5.8$ and solidified with $0.2 \%(w / v)$ GELRITE (Scott Laboratories Inc.).

\subsection{Gamma irradiation}

Irradiation was carried out with a ${ }^{137} \mathrm{Cs}$-gamma source of the Research Center for Nuclear Science and Technology, The University of Tokyo for $2.5 \mathrm{~h}$. Calli were exposed to doses ranging from 5-300 Gy. After irradiation, calli were incubated at $25^{\circ} \mathrm{C}$ for $24 \mathrm{~h}$, then frozen by liquid nitrogen and stored at $-80^{\circ} \mathrm{C}$ until later quantitation of DNA and protein.
2.3 Quantitation of soluble protein and DNA

After the fresh weight was measured, calli were homogenized in extraction buffer $(2 \mathrm{ml} / \mathrm{g}$ of calli) that contained $0.1 \mathrm{M}$ EDTA, $10 \mathrm{mM}$ PMSF, 62.5 mM Tris-HCl pH 6.8, $2 \%(\mathrm{w} / \mathrm{v})$ and $5 \%$ 2-mercaptoethanol with a mortar and pestle. The solution was centrifuged at $15000 \times g$ for 15 min and the supernatant was stored at $-20^{\circ} \mathrm{C}$ for quantitation of DNA. For quantitation of protein, the supernatant was boiled for $3 \mathrm{~min}$ and then stored at $-20^{\circ} \mathrm{C}$. The amount of protein was quantified using a protein assay kit (Bio Rad). Amount of DNA was quantified according to the method of Labarca and Paigen ${ }^{9)}$ using Hoechst 33258.

\section{Results}

\subsection{Effect of gamma irradiation on the growth rate of tobacco calli}

Tobacco calli were transferred to new medium and irradiated with $0,5,10,100$ and $300 \mathrm{~Gy}$ of gamma rays after being cultured for 5 days. After irradiation, the growth of the calli was analyzed until they reached the stationary phase (Fig. 1). The growth of calli appeared to be gradually inhibited as the dose was increased, indicating that gamma irradiation had a severe effect on the viability of cells. The extent of inhibition of the growth rate was similar to that previously observed in tobacco calli ${ }^{10)}$.

\subsection{Effect of gamma irradiation on the amount of soluble protein}

In the absence of gamma irradiation, the amount of protein in the calli decreased from the lag phase ( 5 days after subculture) to the logarithmic phase (19 days after subculture) and decreased again from the logarithmic phase to the stationary phase (35 days after subculture) (Fig. 2A). After being exposed to $0-300 \mathrm{~Gy}$ of gamma 


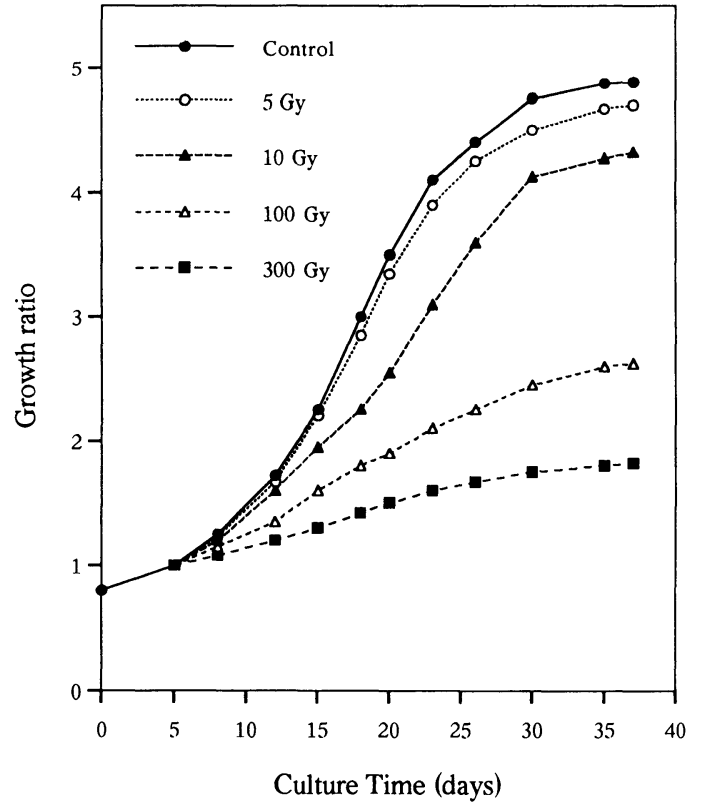

Fig. 1 Growth curve of tobacco calli after gamma irradiation.

Calli were irradiated 5 days after subculture and cultured at $25{ }^{\circ} \mathrm{C}$ in the dark. The growth rate was calculated from the outer dimensions of the callus. Volume of calli at 5 days after subculture is taken as 1.0. The data shows the average of 10 calli for each treatment.

rays and then incubated for $24 \mathrm{~h}$, calli at each stage showed only a slight decrease $(<9 \%)$ in the amount of protein (Fig. 2B).

\subsection{Effect of gamma irradiation on the amount of DNA}

The DNA content of unirradiated calli, like the protein content, decreased with advancing growth phase (Fig. 3A). The decrease in DNA content was greater than the decrease in protein content. When the calli were exposed to gamma radiation and then incubated for $24 \mathrm{~h}$, the DNA content, in contrast to the protein content, was found to decrease significantly with increasing dose of irradiation (Fig. 3 B). The rate of decrease in DNA content was quite similar in each growth stage:
A

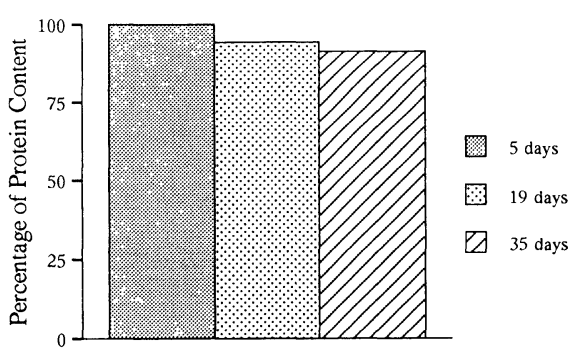

B

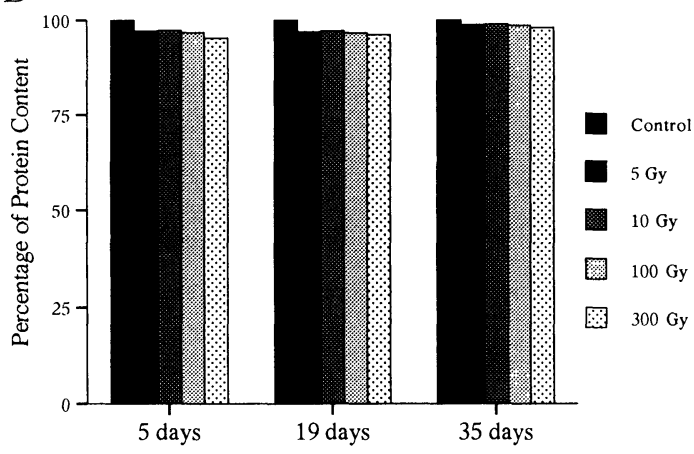

Fig. 2 Effect of gamma irradiation on the amount of soluble protein.

(A) Amounts of protein in unirradiated calli in the lag phase (5 days after subculture), logarithmic phase (19 days after subculture) and stationary phase (35 days after subculture).

(B) Effect of irradiation on the amount of soluble protein of calli at above three phases of growth. The amount of soluble protein of unirradiated calli was assigned a value of $100 \%$.

with a dose of $300 \mathrm{~Gy}$, calli of 5 days, 19 days and 35 days after subculture in new medium had $75.5 \%, 73.5 \%$ and $76.3 \%$ of the DNA levels of unirradiated calli, respectively.

\subsection{The extent of decrease in DNA depends on the time of incubation of calli after irradiation}

It was possible that part or all of the decrease in DNA content of calli following irradiation was due to covalent binding of soluble DNA to cellular components during irradiation. In this case, the amount of DNA after irradiation would be 
A

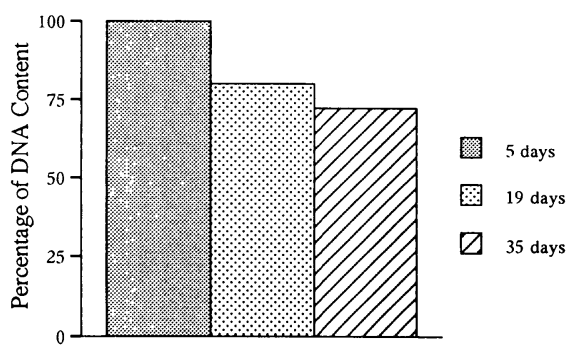

B

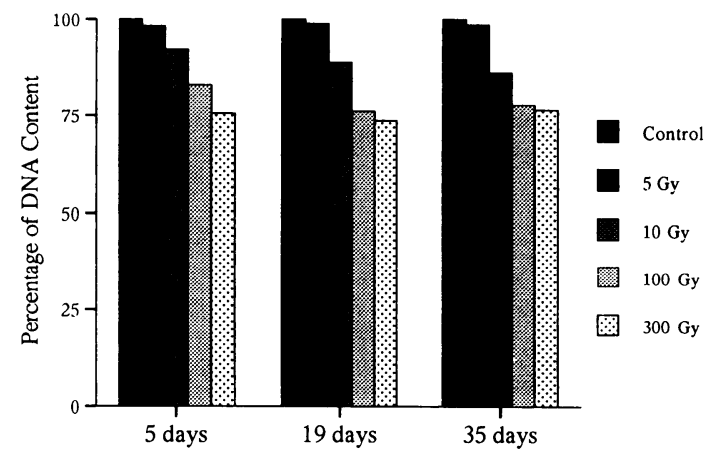

Fig. 3 Effect of gamma irradiation on the amount of DNA.

(A) Amounts of DNA in unirradiated calli in the lag phase, logarithmic phase and stationary phase.

(B) Effect of irradiation on the amount of DNA of calli at above three phases of growth.

The amount of DNA of unirradiated calli was assigned a value of $100 \%$.

expected to be unchanged by incubation following the irradiation, since the formation of covalent bonds would be accomplished during and/or immediately after irradiation. To test this possibility, calli were exposed to $300 \mathrm{~Gy}$ over a period of 2.5 $\mathrm{h}$ and then incubated for $0,1,3,6$ and $24 \mathrm{~h}$ at 25 ${ }^{\circ} \mathrm{C}$. The amount of DNA in the soluble fraction decreased by about $10 \%$ immediately after irradiation and then appeared to decrease with increasing incubation time (Fig. 4). This suggests that the decrease in the amount of DNA occurred in vivo in irradiated calli and was not due to covalent binding of DNA to cellular components.

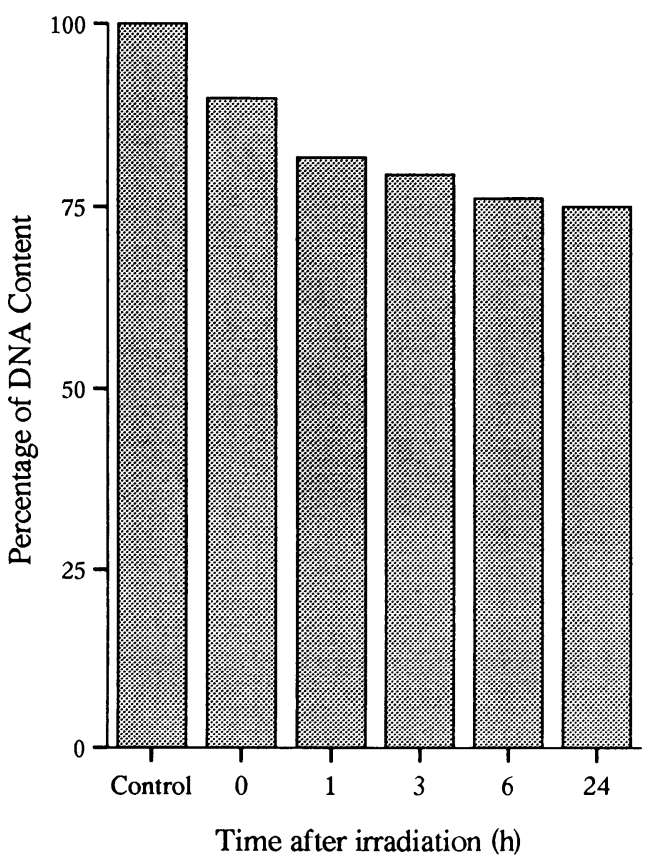

Fig. 4 Decrease in the amount of DNA of calli during incubation after irradiation of $300 \mathrm{~Gy}$ of gamma rays. Irradiated calli and unirradiated controls in the stationary phase were incubated for $0,1,3,6$ and $24 \mathrm{~h}$, and then the amounts of DNA were measured. The amount of unirradiated calli was assigned a value of $100 \%$. Standard errors in repeated measurements were less than $4.8 \%$, which was observed in the case of the incubation for $3 \mathrm{~h}$.

\section{Discussion}

In this study we detected a rapid and significant decrease in the amount of DNA in tobacco calli by gamma irradiation at doses that severely affect the growth of calli, although the level of soluble protein was not greatly changed. A cytological analysis of tobacco pollen mother cells exposed to gamma irradiation showed chromosome breaks followed by elimination of chromosomal fragments and a subsequent reduction in DNA content $^{11)}$. At present, it is not known whether the 
same mechanism(s) were involved in our study. However, the rapid decrease in DNA in the postirradiation period cannot be explained only by a loss of chromosomal fragments generated by irradiation through cell division, since most of the cells of the irradiated calli were unlikely to have undergone cell division within the short period after irradiation. The decrease in DNA with increasing incubation time after irradiation implies that certain enzymatic reactions were induced by irradiation. However, we could not exclude the possibility of suppression of DNA synthesis in these processes.

In animals, chromatin degradation is assumed to be caused by nucleases activated in irradiated cells $^{3}$. If nucleases are involved with the decrease in DNA content observed in the present study, it is possible that the mechanisms that normally suppress nuclease activity are destroyed by irradiation. Nelipovich et al. ${ }^{12)}$ found that $\mathrm{Ca}^{2+} /$ $\mathrm{Mg}^{2+}$-dependent endonuclease was activated in thymocytes of irradiated rats. De novo-synthesized molecules of this enzyme migrate to the cell nucleus and normally exists in an inactive form due to some modification, such as poly ADPribosylation. Nelipovich et al. ${ }^{2)}$ found that with irradiation, the enzyme undergoes no modification and retains its activity, and proposed that this was due to a decrease in the activity of poly (ADP-ribose) polymerase. Degradation of nuclear DNA by irradiation is known to be associated with de novo synthesis of proteins in lymphocytes ${ }^{13)}$. We have detected de novo synthesis of proteins as a result of irradiation: ${ }^{35} \mathrm{~S}$-methionine was incorporated into tobacco calli immediately after irradiation and several newly synthesized labelled proteins that were not synthesized in unirradiated controls were found (unpublished data). Further investigations are needed to clarify the function and significance of these proteins.
Senescence-like phenomena, such as deterioration of microsomal membranes by free radicals, are known to be generated in plant cells during gamma irradiation ${ }^{14}$. Since degradation of DNA and elevated nuclease activity are also known to be involved in the process of senescence of plants ${ }^{15)}$, the present results might reflect an aspect of senescence promoted by ionizing radiation. Recently, several features of programmed cell death in animals have been shown to be induced in plants by a fungal infection ${ }^{16)}$ and salt stress ${ }^{17)}$. In view of these findings, it seems possible that radiation-induced cell death in plants may also occur by apoptotic systems.

\section{References}

1) Soyfer, V. N. : DNA damage and repair in higher plants, Adv. Radiat. Biol., 8, 219-273 (1979)

2) Bajaj, Y. P. S. : Effect of gamma-irradiation on growth, RNA, protein, and nitrogen contents of bean callus cultures, Ann. Bot., 34, 1089-1096 (1970)

3) Melzer, J. M. and O'Connell, M. A. : Effect of radiation dose on the production of and the extent of asymmetry in tomato asymmetric somatic hybrids, Theor. Appl. Genet., 83, 337-344 (1992)

4) Kovtun, Y. V., Korostash, M. A., Butsko, Y. V. and Gleba, Y. Y. : Amplification of repetitive DNA from Nicotiana plumbaginifolia in asymmetric somatic hybrids between Nicotiana sylvestris and Nicotiana plumbaginifolia, ibid., 86, 221-228 (1993)

5) Trick, H., Zelcer, A. and Bates, G. W. : Chromosome elimination in asymmetric somatic hybrids : effect of gamma dose and time in culture, ibid., 88, 965-972 (1994)

6) Samoylov, V. M. and Sink, K. C. : The role of irradiation dose and DNA content of somatic hybrid calli in producing asymmetric plants between an interspecific tomato hybrid and eggplant, ibid., 92, 850-857 (1996)

7) Umansky, S. R., Korol, B. A. and Nelipovich, P. A. : In vivo DNA degradation in thymocytes of $\gamma$-irradiated or hydrocortisone-treated rats, Biochim. Biophys. Acta, 655, 9-17 (1981)

8) Linsmaier, E. and Skoog, F. : Organic growth 
factor requirements of tobacco tissue cultures, Physiol. Plant., 18, 100-127 (1965)

9) Labarca, C. and Paigen, K. : A simple, rapid, and sensitive DNA assay procedure, Anal. Biochem., 102, 344-352 (1980)

10) Balitg, L. P., Hattori, K. and Futsuhara, Y. : Effect of gamma-ray irradiation on the growth of calli in Nicotiana species, Jpn. J. Breed., 39, 29-37 (1989)

11) Muhanna, S., Souvre, A. and Albertini, L. : Effect of gamma rays on nuclear DNA and cellular RNA in meiocytes, microspores and tapetum of Nicotiana tabacum L. var. xanthi Dulieu, Cytologia, 56, 107-115 (1991)

12) Nelipovich, P. A., Nikonova, L. V. and Umansky, S. R. : Inhibition of poly (ADP-ribose) polymerase as a possible reason for activation of $\mathrm{Ca}^{2+} /$ $\mathrm{Mg}^{2+}$-dependent endonuclease in thymocytes of irradiated rats, Int. J. Radiat. Biol., 53, 749-765 (1988)

13) Sellins, K. S. and Cohen, J. J. : Gene induction by gamma-irradiation leads to DNA fragmentation in lymphocytes, J. Immunol., 139, 3199-3206 (1987)

14) Voisine, R., Vezina, L-P. and Willemot, C. : Induction of senescence-like deterioration of microsomal membranes from cauliflower by free radicals generated during gamma irradiation, Plant Physiol., 97, 545-550 (1991)

15) Blank, A. and McKeon, T. A. : Single-strandpreferring nuclease activity in wheat leaves is increased in senescence and is negatively photoregulated, Proc. Natl. Acad. Sci. USA, 86, 3169-3173 (1989)

16) Greenberg, J. T., Guo, A., Klessig, D. F. and Ausubel, F. M. : Programmed cell death in plants : a pathogen-triggered response activated coordinately with multiple defense functions, Cell, 77, 551-563 (1994)

17) Katsuhara, M. and Kawasaki, T. : Salt stress induced nuclear and DNA degradation in meristematic cells of barley roots, Plant Cell Physiol., 37, 169-173 (1996) 